\title{
Marine meiofauna, carbon and nitrogen mineralization in sandy and soft sediments of Disko Bay, West Greenland
}

\author{
Søren Rysgaard ${ }^{1, *}$, Peter Bondo Christensen ${ }^{1}$, Martin V. Sørensen ${ }^{2}$, Peter Funch ${ }^{3}$, \\ Peter Berg ${ }^{4}$
}

'Dept. of Lake and Estuarine Ecology, National Environmental Research Institute, Vejlsøvej 25, 8600 Silkeborg, Denmark

${ }^{2}$ Zoological Museum, Dept. 2, University of Copenhagen, Universitetsparken 15, 2100 Copenhagen $\varnothing$, Denmark

${ }^{3}$ Dept. of Zoology, Institute of Biological Sciences, University of Aarhus, 8000 Århus C, Denmark

${ }^{4}$ Dept. of Environmental Sciences, University of Virginia, Charlottesville, Virginia 22903, USA

\begin{abstract}
Organic carbon mineralization was studied in a shallow-water $(4 \mathrm{~m})$, sandy sediment and 2 comparatively deep-water (150 and $300 \mathrm{~m}$ ), soft sediments in Disko Bay, West Greenland. Benthic microalgae inhabiting the shallow-water locality significantly affected diurnal $\mathrm{O}_{2}$ conditions within the surface layers of the sediment. Algal photosynthetic activity and nitrogen uptake reduced nitrogen effluxes and denitrification rates. Sulfate reduction was the most important pathway for carbon mineralization in the sediments of the shallow-water station. In contrast, high bottom-water $\mathrm{NO}_{3}{ }^{-}$concentrations and a relatively deep $\mathrm{O}_{2}$ penetration into the sediment at the deep-water stations ensured high denitrification activity, particularly as a result of an efficient coupling between nitrification and denitrification. Denitrification accounted for up to $33 \%$ of total carbon mineralization in the deep-water sediment and was, together with organotrophic $\mathrm{O}_{2}$ respiration, the most important pathway for carbon mineralization within these sediments. The obtained process rates were comparable to mineralization rates from much warmer localities, suggesting that benthic mineralization in arctic marine environments is regulated primarily by the availability of organic matter and not by temperature. The shallow-water sediment contained a larger meiofauna population than the deep-water muddy sediments. Crustacean nauplia dominated the upper $9 \mathrm{~mm}$ while nematodes dominated below. A typical interstitial fauna of species belonging to Platyhelminthes, Rotitera, Gastrotricha, and Protodriloidae (Polychaeta) occurred only at the sandy locality, whereas Kinorhyncha, Foraminifera, and Cumacea (Crustacea) occurred only at the muddy stations. The larger number of meiofauna individuals at the sandy locality may in part be explained by higher food availability, as living diatoms served as food for the meiofauna. Based on interpretation of the vertical $\mathrm{O}_{2}$ concentration profiles compared with intact-core $\mathrm{O}_{2}$ flux measurements, it was shown that the bioturbation coefficient was approximately 3 times higher in the sandy sediment, corresponding to the 3 times higher number of meiofauna found in the upper $2 \mathrm{~cm}$ of this sediment. Thus, meiofauna increased the transport of solutes as compared to molecular diffusion by a factor of 1.5 to 3.1 , thereby stimulating microbial mineralization.
\end{abstract}

KEY WORDS: Arctic - Sediment $\cdot$ Mineralization - Meiofauna $\cdot$ Carbon cycling $\cdot$ Denitrification

\section{INTRODUCTION}

A number of studies on pelagic food web structure and water column processes have recently been reported from Disko Bay, West Greenland (Smidt 1979, Andersen 1981, Nielsen \& Hansen 1995, 1999, Hansen

•E-mail: sr@dmu.dk et al. 1999, Levinsen et al. 1999). Despite increasing knowledge of organisms and processes in the water column, only a few studies have focused on the sediments of Disko Bay or other areas along the west coast of Greenland.

Organic carbon mineralization within the sediment, however, has been described for other arctic areas over the last 2 decades (Pfannkuche \& Thiel 1987, Grebmeier \& McRoy 1989, Henriksen et al. 1993, Devol et al. 
1997, Glud et al. 1998, Rysgaard et al. 1998, Sagemann et al. 1998). These studies have shown that rates of benthic mineralization in arctic sediments can be as high as those measured in temperate and tropical sediments (Patmatmat 1973, Rasmussen \& Jørgensen 1992, Tahey et al. 1994, Thamdrup et al. 1996), and it has been suggested that carbon degradation in these permanently cold sediments is not limited by low temperatures but by carbon availability. Furthermore, increasing knowledge of the relative importance of aerobic and anaerobic carbon oxidation pathways has recently been acquired from both temperate and arctic areas (Canfield et al. 1993, Jørgensen 1996, Thamdrup \& Canfield 1996, Devol et al. 1997, Rysgaard et al. 1998).

The upper layer of marine sediments, characterized by a high microbial activity and steep gradients in solutes, typically contains an abundant meiofauna community, ranging from $\sim 10$ to $\sim 500$ ind $\mathrm{cm}^{-3}$. The composition of the meiofauna varies both vertically and horizontally in the sediment due to differences in grain size and physiochemical factors, particularly temperature, oxygen, and salinity (Nybakken 1997). Furthermore, it has been shown that meiofauna can enhance transport of solutes in sediments (Aller \& Aller 1992, Berg et al. 1999, Glud \& Fenchel 1999) and thereby increase the carbon mineralization in the upper sediment layers. The benthic meiofauna from west Greenland is known from taxonomic studies on Annelida (Kristensen \& Niilonen 1982, Kristensen \& Norrevang 1982), Kinorhyncha (Higgins \& Kristensen 1988) and Rotifera (Sørensen 1998).

The aim of the present study was to investigate organic carbon mineralization in sandy, shallow-water sediment and soft sediments of deeper waters in Disko Bay. We evaluate the relative importance of $\mathrm{O}_{2}$, $\mathrm{NO}_{3}{ }^{-}$, and $\mathrm{SO}_{4}{ }^{2-}$ as terminal $\mathrm{e}^{-}$-acceptors in the oxidation of organic matter within the sediment and include the vertical distribution and density of meiofauna in estimates of the solute transports within the sediments. The present study also provides the first quantitative estimate of a true interstitial fauna from the subtidal zone in the Arctic.

\section{MATERIAL AND METHODS}

Study site. The investigation was carried out at 3 localities in Disko Bay, West Greenland. All samples were collected in midJune 1997 at 3 sites: 1 sandy sediment and 2 muddy sediments. Stn 1 was positioned off the sandy beach Iterlaa on the southeast coast of Disko Island (Fig. 1), and the sam- ples were collected at high tide (water depth of $4 \mathrm{~m}$ ). Stn 2 (water depth of $150 \mathrm{~m}$ ) and Stn 3 (water depth of $300 \mathrm{~m}$ ) were positioned off the locality Kuannit on the southern coast of Disko Island

The water column of Disko Bay is stratified due to a combination of increased air temperature, freshwater input from the sea ice and meltwater runoff from land during the summer thaw. During stratification a layer with salinity less than $33 \%$ and temperature above $5^{\circ} \mathrm{C}$ forms the upper 10 to $20 \mathrm{~m}$ of the water column. This stratification causes nutrients to be depleted in the upper photic zone due to phytoplankton uptake (Nielsen \& Hansen 1995). During autumn, temperature becomes uniform down to $15 \mathrm{~m}$ and salinity stratification less pronounced, initiating the destabilization of the water column. The hydrographic conditions of Disko Bay are described in further detail in Petersen (1964) and in Nielsen \& Hansen (1999).

Sediment and water sampling. Sediment was sampled using a core sampler (Kanneworff \& Nicolaisen 1973) from RV 'Porsild'. Sub-samples were taken within each sediment core using cylindrical Plexiglas tubes $\left(22 \mathrm{~cm}^{2}\right)$. Only undisturbed sediment cores with clear overlying water were used for further processing. All sediment cores were immediately placed in an insulated box and brought back to the laboratory

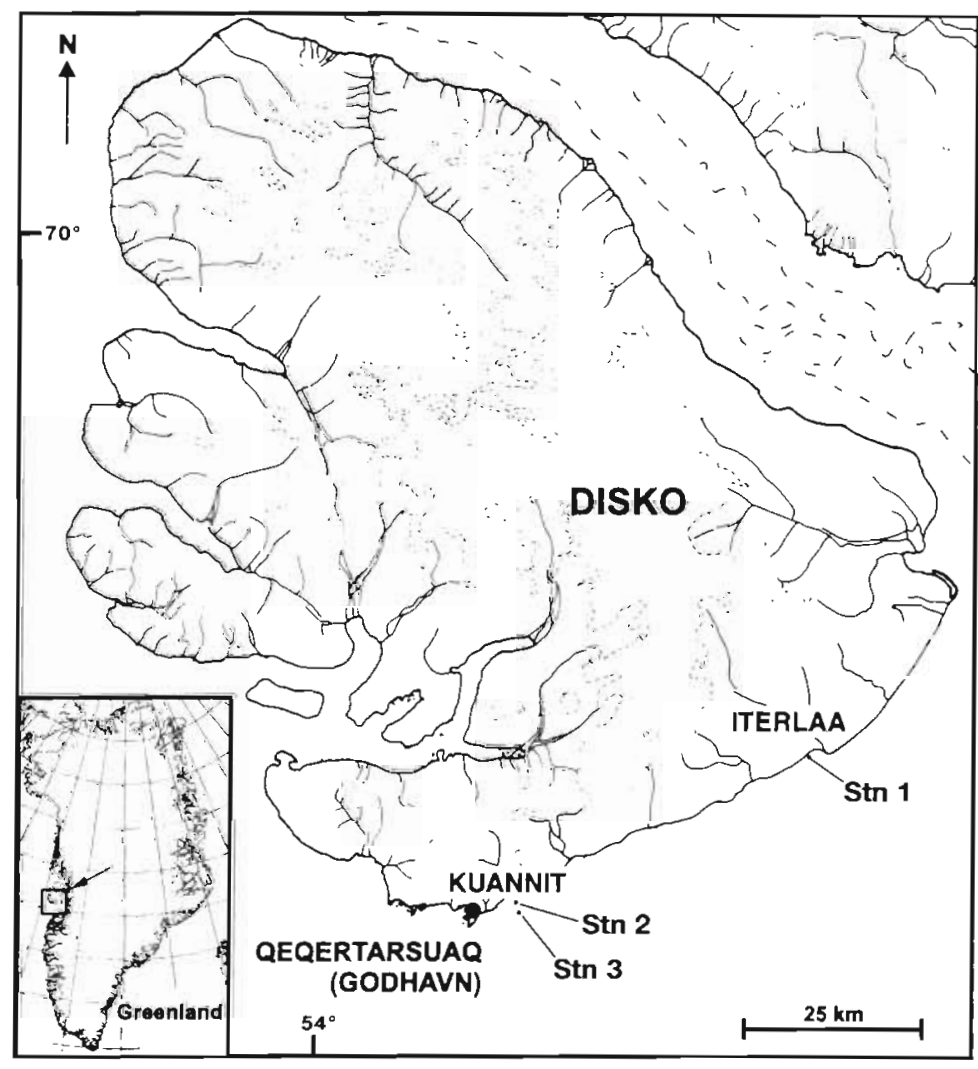

Fig. 1. Location of the investigated stations in Disko Bay, West Greenland 
within $5 \mathrm{~h}$. Bottom water was collected with a 51 Niskin water sampler. In the laboratory, a small Teflon-coated magnet $(0.5 \times 3 \mathrm{~cm})$ was placed $5 \mathrm{~cm}$ above the sediment surface in each core and the cores from each locality were submerged in separate tanks with in situ bottom water and kept in darkness at in situ temperature and air saturation. Mixing of the water column was provided by rotating the Teflon coated magnets (60 rpm). All cores were pre-incubated for $1 \mathrm{~d}$ before further processing.

Sediment characteristics. Porosity was calculated from density and water content in 0.5 to $1 \mathrm{~cm}$ fractions of 4 sediment cores, and the water content measured as weight loss of a known volume after drying at $105^{\circ} \mathrm{C}$ for $24 \mathrm{~h}$. Organic carbon and nitrogen content was determined on 4 replicate sediment cores sliced into 0.3 to $1 \mathrm{~cm}$ fractions and frozen for later analysis. Prior to analysis each fraction was freeze dried, homogenized, weighed into sample boats and treated with $\mathrm{HCl}$. Analyses were performed on a $\mathrm{C} / \mathrm{N}$ elemental analyzer (RoboPrep-C/N, Europa Scientific, UK).

Sediment porewater chemistry. Vertical concentration profiles of $\mathrm{O}_{2}$ were measured with a Clark-type $\mathrm{O}_{2}$ microelectrode (Revsbech 1989) at $200 \mu \mathrm{m}$ intervals in 3 intact sediment cores from the shallow-water Stn 1 and the deep-water Stn 3. Measurements were performed at in situ temperature with an overlying water column of $2 \mathrm{~cm}$, aerated by a flow of atmospheric air to ensure sufficient stirring of the water column while measuring. Oxygen concentration profiles from Stn 3 were measured in the dark. At $\mathrm{Stn} 1, \mathrm{O}_{2}$ concentration profiles were measured at 3 light intensities, maximum, intermediate and minimum light intensity measured at the sediment surface $(350,30$ and $9 \mu \mathrm{mol}$ photons $\mathrm{m}^{-2} \mathrm{~s}^{-1}$, respectively), and in darkness

Porewater extractions for measurement of vertical concentration profiles of $\mathrm{NH}_{4}{ }^{+}, \mathrm{NO}_{3}{ }^{-}, \mathrm{Fe}^{2+}, \mathrm{Mn}^{2+}, \mathrm{H}_{2} \mathrm{~S}$ and $\mathrm{SO}_{4}{ }^{2-}$ were made using a pneumatic squeezer (modified after Reeburgh 1967) and applying a pressure of 2 bar on sediment from Stn 3. Sectioning and squeezing took place in an $\mathrm{N}_{2}$-filled glove bag to avoid oxidation of the compounds. Two to three cores were used for sampling each of these parameters. The cores for $\mathrm{NH}_{4}{ }^{+}$and $\mathrm{NO}_{3}{ }^{-}$ determination were sectioned into 3 to $10 \mathrm{~mm}$ slices and porewater extracted through Whatman GF/F glass-fiber filters and frozen immediately $\left(-18^{\circ} \mathrm{C}\right)$ in $5 \mathrm{ml}$ plastic vials. On parallel cores with the same sediment fractions, porewater was extracted through $0.45 \mu \mathrm{m}$ cellulose acetate filters, and acidified with $\mathrm{HCl}$ to $\mathrm{pH} 2\left(\mathrm{Mn}^{2+}\right.$ and $\mathrm{Fe}^{2+}$ ) or fixed with $\mathrm{Zn}$ acetate to a final concentration of $0.5 \%\left(\mathrm{H}_{2} \mathrm{~S}\right.$ and $\left.\mathrm{SO}_{4}{ }^{2-}\right)$ and frozen until later analysis.

Concentrations of $\mathrm{NH}_{4}{ }^{+}$and $\mathrm{NO}_{3}{ }^{-}$were measured in $100 \mu$ samples using the small-volume flow injection techniques described by Hall \& Aller (1992) and by Braman \& Hendrix (1989). Dissolved $\mathrm{Fe}^{2+}$ in porewater samples was determined by colorimetry with a ferrozine solution without reducing agent (Stookey 1970). Dissolved $\mathrm{Mn}^{2+}$ was analyzed by flame atomic absorption spectroscopy. Sulfate was determined by non-suppressed anion chromatography, and $\mathrm{H}_{2} \mathrm{~S}$ was quantified by the methylene-blue technique (Cline 1969).

Sediment solid-phase chemistry. The depth distributions of total reduced sulfur species were determined in 3 cores for both Stns 1 and 3. Total reduced inorganic sulfur was measured using the single distillation step procedure (Fossing \& Jørgensen 1989).

Sediment-water fluxes. At all stations, exchange of $\mathrm{O}_{2}, \mathrm{DIC}, \mathrm{NO}_{3}{ }^{-}+\mathrm{NO}_{2}{ }^{-}$, and $\mathrm{NH}_{4}^{+}$between water column and sediment was measured on 6 intact cores $24 \mathrm{~h}$ after sampling. The sediment height was adjusted to give sediment and water columns of $\sim 12$ and $\sim 20 \mathrm{~cm}$, respectively. As in the pre-incubation period, the water column was continuously stirred during the flux-rate experiments. The sediment cores were incubated in darkness at in situ temperature.

Flux measurements were initiated by closing the cores with a floating gas-tight lid. To prevent gas exchange between water and the ambient atmosphere, the lids were carefully removed only when water samples were collected. During incubation (14 to $24 \mathrm{~h}$ ) water samples were collected 4 to 5 times in order to verify a linear reduction in concentration over time and to ensure that the reduction in $\mathrm{O}_{2}$ concentration in the water column did not exceed $20 \%$ of the initial $\mathrm{O}_{2}$ concentration.

Oxygen concentrations in the water samples were analyzed by Winkler titration within 12 h of sampling, and filtered (Whatmann GF/F glass-fiber) water samples were frozen immediately $\left(-18^{\circ} \mathrm{C}\right)$ for later nutrient analysis. Water samples for DIC concentration determination were preserved in glass vials (Exetainer ${ }^{\circledast}$, Labco, High Wycombe, UK) with $50 \mu \mathrm{HgCl}_{2}(5 \% \mathrm{w} / \mathrm{v})$. DIC concentrations were measured on a $\mathrm{CO}_{2}$ analyzer (Coulometer CM5012, UIC Inc. Joliet, IL, USA). Concentrations of $\mathrm{NO}_{3}{ }^{-}+\mathrm{NO}_{2}{ }^{-}$were determined on a flow injection analyzer (Alpkem FS3000, Perstorp Analytical Environmental Inc., OR, USA) using the method described by Grasshoff et al. (1983). Ammonium concentrations were determined using the method of Bower \& Holm-Hansen (1980).

Sediment denitrification rates. At all stations, the rate of denitrification was determined using the isotope pairing technique (Nielsen 1992) as described by Risgaard-Petersen \& Rysgaard (1995) and Rysgaard et al. (1995). In short, ${ }^{15} \mathrm{NO}_{3}{ }^{-}$was added to the overlying water ( $-50 \mu \mathrm{M}$ final concentration) to initiate incubation, and cores were closed with rubber stoppers leaving no headspace. Six sediment cores from each site were incubated and processed at different time intervals during the 14 to $24 \mathrm{~h}$ incubation period. After in- 
cubation, sub-samples of water column and sediment were collected for analysis of the ${ }^{15} \mathrm{~N}$ labelling of $\mathrm{N}_{2}$ and $\mathrm{NO}_{3}{ }^{-}$. The samples for the ${ }^{15} \mathrm{~N}$ abundance in $\mathrm{NO}_{3}{ }^{-}$ were frozen $\left(-18^{\circ} \mathrm{C}\right)$ until later analysis and samples for ${ }^{15} \mathrm{~N}-\mathrm{N}_{2}$ analysis were preserved in glass vials containing $2 \%$ (vol.) of a $\mathrm{ZnCl}_{2}$ solution $(50 \% \mathrm{w} / \mathrm{v}$ ).

The abundance and the concentration of ${ }^{14} \mathrm{~N}^{15} \mathrm{~N}$ and ${ }^{15} \mathrm{~N}^{15} \mathrm{~N}$ were analyzed on a gas chromatograph coupled to a triple-collector isotopic ratio mass spectrometer (RoboPrep- $\mathrm{G}^{+}$in line with TracerMass, Europa Scientific, Crewe, UK) as described by Risgaard-Petersen $\&$ Rysgaard (1995). The ${ }^{15} \mathrm{~N}$ isotopic distribution in the $\mathrm{NO}_{3}{ }^{-}$pool was likewise analyzed by mass spectrometry after reduction of $\mathrm{NO}_{3}{ }^{-}$to $\mathrm{N}_{2}$ using a denitrifying bacterial culture (Risgaard-Petersen et al. 1993).

Sulfate reduction rates. Sulfate reduction rates were determined in intact sediment cores from Stns 1 and 3 by the ${ }^{35} \mathrm{SO}_{4}{ }^{2-}$ tracer method (Jørgensen 1978). Five $\mu \mathrm{l}$ portions of carrier-free ${ }^{35} \mathrm{SO}_{4}{ }^{2-}\left(80 \mathrm{kBq} \mu l^{-1}\right.$; Risø Isotope Laboratory, Denmark) were injected into 2 sediment cores (inner diameter $26 \mathrm{~mm}$ ) at $1 \mathrm{~cm}$ intervals through silicone-sealed ports in the tube wall from the sediment surface and down to $15 \mathrm{~cm}$ depth. The cores were incubated at in situ temperature in the dark, and after $24 \mathrm{~h}$ the cores were sliced into $1 \mathrm{~cm}$ sections which were transferred immediately to plastic centrifuge tubes containing $10 \mathrm{ml} 20 \% \mathrm{ZnAc}$, mixed, and stored frozen $\left(-18^{\circ} \mathrm{C}\right)$ until analysis. The concentration of $\mathrm{SO}_{4}{ }^{2-}$ was determined in each sediment fraction by unsuppressed anion chromatography using a Waters 510 HPLC pump, Waters WISP 712 autosampler (100 $\mu 1$ injection volume), a Waters IC-Pak anion exchange column $(50 \times 4.6 \mathrm{~mm})$, and a Waters 430 conductivity detector. Rates of sulfate reduction were measured and calculated as described by Fossing \& Jørgensen (1989).

Meiofauna. The vertical distribution and the density of meiofauna in the sediment from Stns 1 and 3 were determined on cores sectioned into 3 to $10 \mathrm{~mm}$ depth intervals. Each section was transferred to a plastic tube and then preserved with $5 \%$ formalin buffered with borax. Before preservation, an isotonic solution of $\mathrm{MgCl}_{2}$ was added to anaesthetize the meiofauna (see Pfannkuche \& Thiel 1988).

The meiofauna from each section was stained with rose bengal, collected on a $30 \mu \mathrm{m}$ sieve, and examined through a Zeiss stereomicroscope at $40 \times$ magnification. Most of the meiofauna was only identified to higher taxonomic levels, i.e. phylum or class, while some was identified to lower levels, i.e. order, family, genus (gastrotrichs and some platyhelminthes, annelids and nematodes) or even species level (rotifers). The number of representatives from each taxon was determined, and the numbers were converted to ind. $\mathrm{cm}^{-3}$, to compare vertical distribution of meiofauna at shallow and deep stations, respectively.

\section{RESULTS}

\section{Sediment characteristics}

The porosity and density of the sandy, shallow-water station was significantly different from those of the 2 deep-water, muddy stations (Table 1, Fig. 2). The porosity measured at each individual depth of both Stns 1 and 3 was fitted (Stn 1: $0.38+0.070 \exp$ [-0.93depth] and Stn 3: $0.68+0.19 \exp [-0.57$ depth]), for interpretations of concentration profiles (see below).

Table 1. Physical and chemical parameters of the 3 stations in Disko Bay. Porosity and density are given as depth-averaged values

\begin{tabular}{|lccc|}
\hline & $\begin{array}{c}\text { Stn 1, } \\
\text { Itarlad, 4 m }\end{array}$ & $\begin{array}{c}\text { Stn 2, } \\
\text { Kuannit, 150 m }\end{array}$ & $\begin{array}{c}\text { Stn 3, } \\
\text { Kuannit, 300 m }\end{array}$ \\
\hline Bottom water & & & \\
Temperature $\left({ }^{\circ} \mathrm{C}\right)$ & 8.8 & 1.0 & 1.0 \\
Salinity (psu) & 32.2 & 33.4 & 33.4 \\
$\mathrm{NH}_{4}{ }^{+}(\mu \mathrm{M})$ & 0.5 & 0.7 & 0.9 \\
$\mathrm{NO}_{3}{ }^{-}(\mu \mathrm{M})$ & 0.1 & 13.4 & 12.3 \\
Sediment & & & \\
Type & Sand & Mud & Mud \\
Porosity $\left(\mathrm{ml} \mathrm{cm}^{-3}\right)$ & 0.4 & 0.6 & 0.7 \\
Density $\left(\mathrm{g} \mathrm{cm}^{-3}\right)$ & 1.9 & 1.5 & 1.4 \\
\hline
\end{tabular}

The organic carbon content in the sediment at both the $4 \mathrm{~m}$ and the $300 \mathrm{~m}$ station decreased with sediment depth (Fig. 2). Little organic carbon was present at the shallow-water, sandy Stn 1, where most organic carbon was found in the upper 2 to $3 \mathrm{~cm}$. The organic carbon content also decreased with depth at the deepwater, muddy Stn 3 although the decrease was not as pronounced as at Stn 1 . The C:N ratio at the shallowwater station was low ( 6 to 8 ) and comparable to the Redfield ratio (106:16), suggesting that most of the organic material was freshly sedimented algal material, whereas the $C: N$ ratio was higher $(10$ to 12$)$ at the deep-water Stn 3, presumably due to degradation of sedimenting organic matter in the water column. At both stations a slight increase in the $C: N$ ratio with depth was observed (Fig. 2).

\section{Sediment porewater}

Porewater $\mathrm{O}_{2}$ concentrations varied between shallow and deep waters of Disko Bay due to the presence of benthic microalgae in shallow-water areas as well as large differences in activity levels of $\mathrm{O}_{2}$-consuming processes. In the dark-incubated sediment cores, $\mathrm{O}_{2}$ penetrated approximately $0.2 \mathrm{~cm}$ into the shallowwater sediment, whereas $\mathrm{O}_{2}$ penetrated approximately 

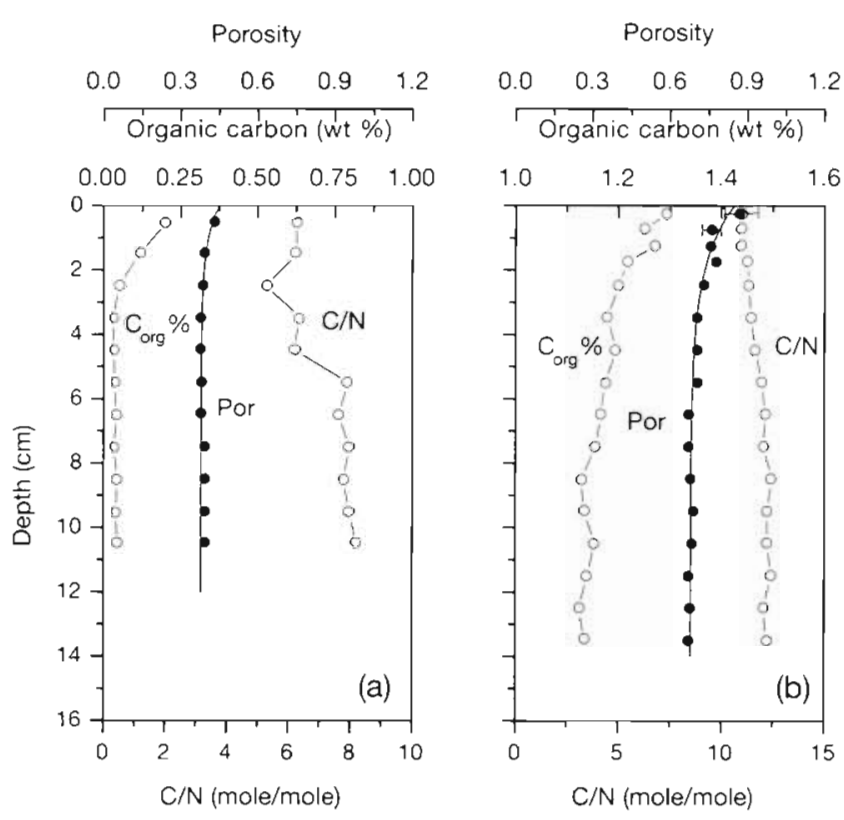

Fig. 2. Depth distribution of porosity, organic carbon $\left(\mathrm{C}_{\mathrm{org}} \%\right)$, and $\mathrm{C} / \mathrm{N}$ ratios in the sediment of (a) the shallow-water, sandy station and (b) the $300 \mathrm{~m}$, muddy station. Note the difference in scales of organic carbon and C:N ratio between (a) and (b)

$0.6 \mathrm{~cm}$ into the sediment of the $300 \mathrm{~m} \mathrm{Stn} 3$ (Fig. 3). Oxygen consumption as a function of depth was calculated using the numerical procedure described by Berg et al. (1998) for interpretation of porewater concentration profiles. The molecular diffusion coefficient for $\mathrm{O}_{2}$ in free water $\left(11.7 \times 10^{-6} \mathrm{~cm}^{2} \mathrm{~s}^{-1}\right)$ was taken from Broecker \& Peng (1974), corrected for tortuosity as described by Iversen \& Jørgensen (1993) and using a bioturbation coefficient of $11.9 \times 10^{-6} \mathrm{~cm}^{2} \mathrm{~s}^{-1}$ for Stn 1 and a bioturbation coefficient of $4.0 \times 10^{-6} \mathrm{~cm}^{2} \mathrm{~s}^{-1}$ for Stn 3 (see 'Discussion'). The $\mathrm{O}_{2}$ consumption based on electrode measurements in darkness for the shallowwater Stn 1 was $14.4 \mathrm{mmol} \mathrm{m}^{-2} \mathrm{~d}^{-1}$ (Fig. 3a) and for the $300 \mathrm{~m} \mathrm{Stn} \mathrm{3,8.0} \mathrm{mmol} \mathrm{m}^{-2} \mathrm{~d}^{-1}$ (Fig. 3b). The interpretation of both profiles shows a relatively high $\mathrm{O}_{2}$ consumption near the oxic-anoxic interface, presumably due to nitrification and to reoxidation of reduced products being transported upwards to the oxic zone.

Benthic microalgae caused diurnal variations in the $\mathrm{O}_{2}$ concentration profile at the shallow-water Stn 1 and resulted in an $\mathrm{O}_{2}$ penetration of $-3.5 \mathrm{~mm}$ during daytime and $\sim 1.5 \mathrm{~mm}$ at night (Fig. 4). Interpretation of the $\mathrm{O}_{2}$ profiles at maximum light intensity resulted in a net $\mathrm{O}_{2}$ production of $69.2 \mathrm{mmol} \mathrm{m} \mathrm{m}^{-2} \mathrm{~d}^{-1}$ in a narrow zone of 0 to $1.5 \mathrm{~mm}$ below the sediment-water interface due to benthic microalgal photosynthesis, whereas a net $\mathrm{O}_{2}$ consumption of $27.3 \mathrm{mmol} \mathrm{m}^{-2} \mathrm{~d}^{-1}$ was observed below this depth (Fig. 4). In total, the shallow-water sediment exhibited a net $\mathrm{O}_{2}$ production during the daytime (41.9 $\left.\mathrm{mmol} \mathrm{m}^{-2} \mathrm{~d}^{-1}\right)$.

Porewater concentration of $\mathrm{NH}_{4}{ }^{+}$at the $300 \mathrm{~m}$ station increased from $0.9 \mu \mathrm{M}$ in the bottom water to $\sim 60 \mu \mathrm{M}$ at $8 \mathrm{~cm}$ depth, below which it remained almost constant (Fig. 5a). The vertical distribution of $\mathrm{NH}_{4}{ }^{+}$production was calculated as described by Berg et al.
Fig. 3. Vertical $\mathrm{O}_{2}$ concentration profiles ( ) and consumption rates (bars) in (a) the shallow-water, sandy sediment inhabited by benthic microalgae in darkness, and (b) at the $300 \mathrm{~m}$ station in Disko Bay. Error bars represent standard error, $\mathrm{n}=3$
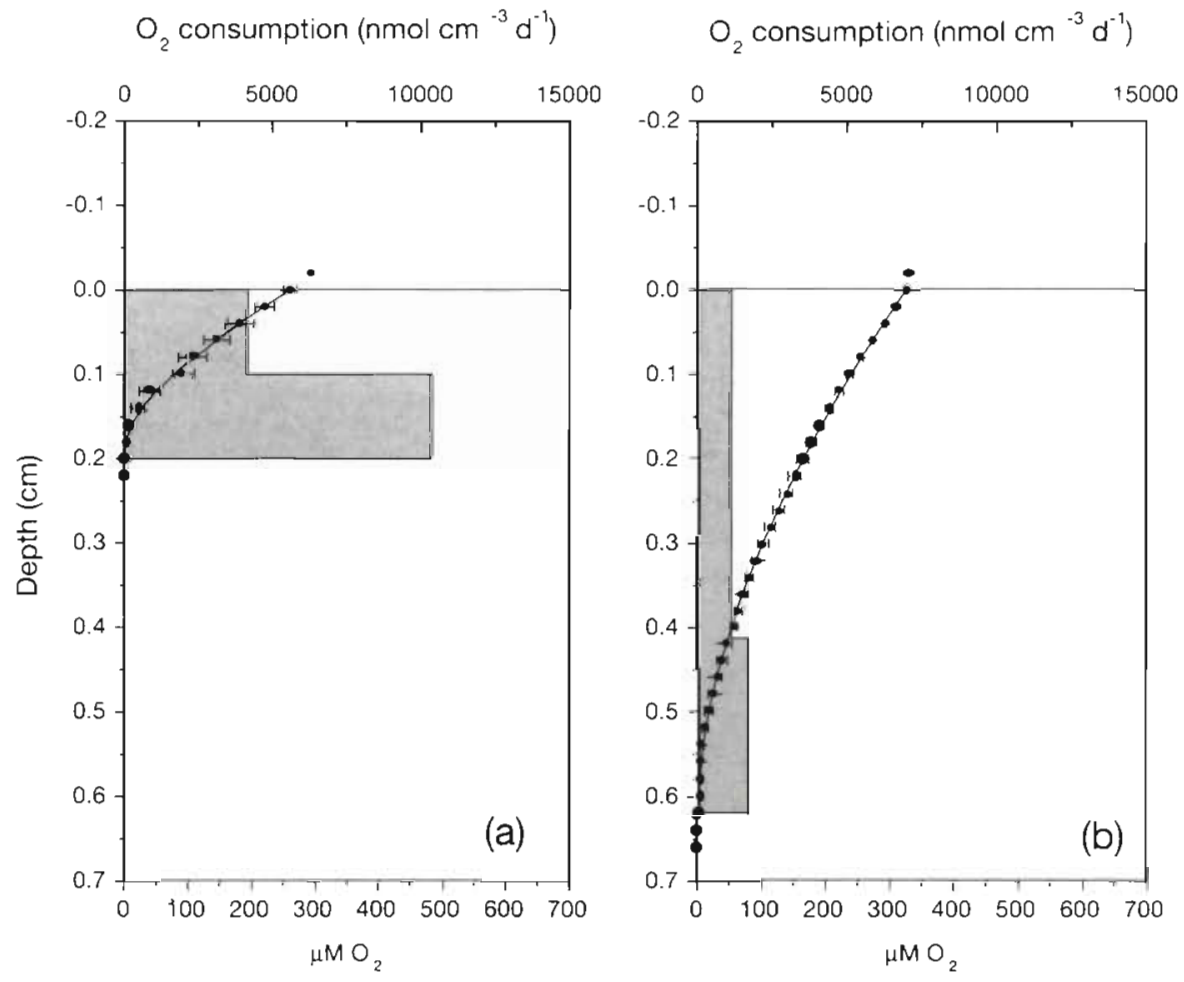
(1998). The diffusion coefficient for free water $\left(9.8 \times 10^{-6} \mathrm{~cm}^{2} \mathrm{~s}^{-1}\right)$ was taken from Li \& Gregory (1974) and corrected for tortuosity for a muddy sediment as described by Iversen \& Jørgensen (1993) and using a bioturbation coefficient of $4.0 \times 10^{-6} \mathrm{~cm}^{2} \mathrm{~s}^{-1}$. The production profile consisted of 3 distinct zones. A net $\mathrm{NH}_{4}{ }^{+}$consumption zone in the upper oxic layer of the sediment, a relatively high $\mathrm{NH}_{4}{ }^{+}$production zone just below the oxic layer of the sediment, and a larger zone of low $\mathrm{NH}_{4}{ }^{+}$production extending deeper into the sediment.

Bacterial nitrification in the upper $0.6 \mathrm{~cm}$ of the sediment, where both $\mathrm{O}_{2}$ and $\mathrm{NH}_{4}{ }^{+}$ were present, increased the porewater $\mathrm{NO}_{3}{ }^{-}$ concentration from $\sim 12 \mu \mathrm{M}$ in the overlying water to $\sim 20 \mu \mathrm{M}$. Below the oxic zone, the $\mathrm{NO}_{3}{ }^{-}$concentration decreased due to the activity of denitrifying bacteria (Fig. 5b).

The concentrations of $\mathrm{Mn}^{2+}$ and $\mathrm{Fe}^{2+}$ in the sediment of Stn 3 increased from the surface

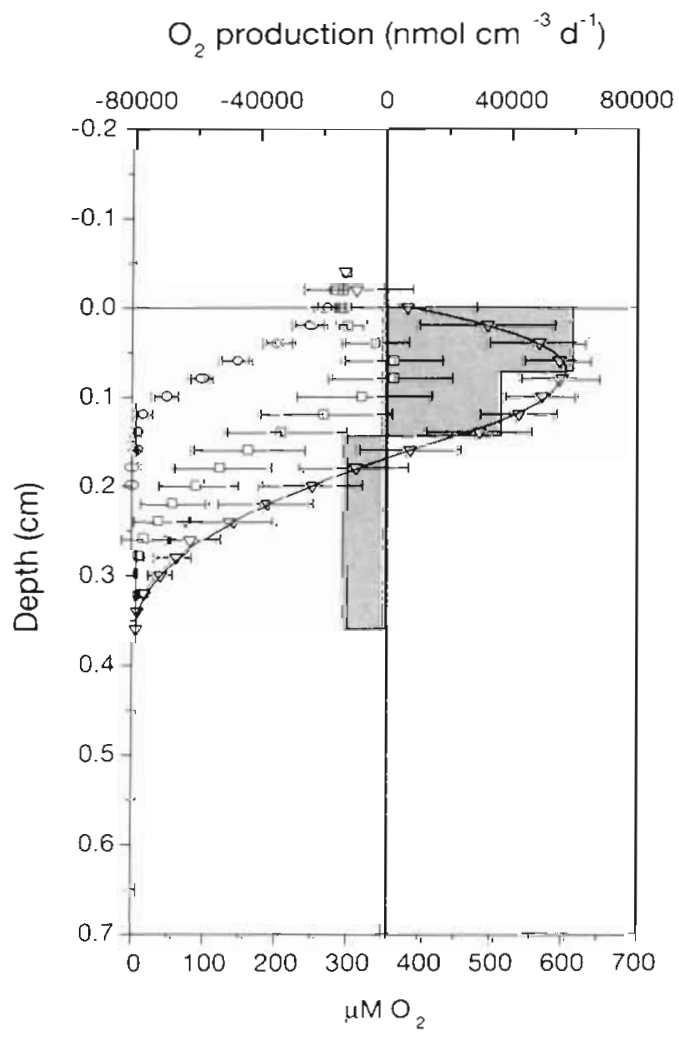

Fig. 4. Vertical $\mathrm{O}_{2}$ concentration profiles at 3 different light intensities $\left(0: 9, \square: 30, \nabla: 350 \mathrm{\mu mol}\right.$ photons $\left.\mathrm{m}^{-2} \mathrm{~s}^{-1}\right)$ and the production rates at maximum light intensity (bars) in the shallowwater, sandy sediment inhabited by benthic microalgae during a diurnal cycle. A negative production rate is equal to an $\mathrm{O}_{2}$ consumption rate. Error bars represent standard error, $\mathrm{n}=3$

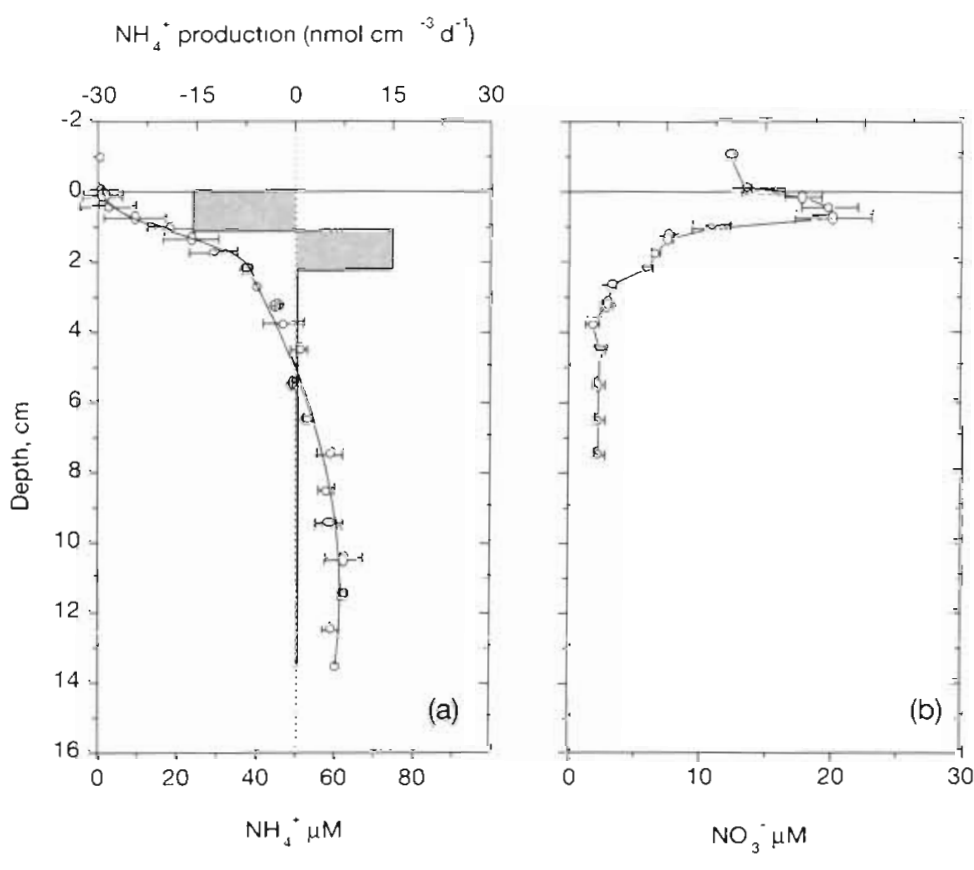

Fig. 5. (a) Vertical concentration profiles of $\mathrm{NH}_{4}{ }^{+}$(symbols and lines) and simulated $\mathrm{NH}_{4}{ }^{+}$production rates (bars). A negative production rate is equal to a $\mathrm{NH}_{4}{ }^{+}$consumption rate. (b) Nitrate concentration profiles at the $300 \mathrm{~m}$ locality in Disko Bay. Error bars represent standard error, $\mathrm{n}=3$

sediment layer to 10 and $90 \mu \mathrm{M}$ at 2 and $5 \mathrm{~cm}$, respectively (Fig. 6a). The concentration of $\mathrm{SO}_{4}{ }^{2-}$ was $28 \mathrm{mM}$ in the overlying water and no gradient was detected in the porewater of the upper $15 \mathrm{~cm}$ of the sediment (data not shown). Free $\mathrm{H}_{2} \mathrm{~S}$ was never detected in the porewater (detection limit $1 \mu \mathrm{M}$ ). Reduced sulfur $\left(\mathrm{S}^{0}+\mathrm{FeS}+\right.$ $\mathrm{FeS}_{2}$ ) increased from low levels in the surface sediment to $60 \mu \mathrm{mol} \mathrm{cm} \mathrm{cm}^{-3}$ at 5 to $9 \mathrm{~cm}$ depth, below which concentrations decreased (Fig. 6b).

\section{Sediment-water fluxes}

The sediment $\mathrm{O}_{2}$ uptake decreased with depth from $\sim 14 \mathrm{mmol} \mathrm{m}^{-2} \mathrm{~d}^{-1}$ at $4 \mathrm{~m}$ depth to $\sim 10$ and $\sim 8 \mathrm{mmol}$ $\mathrm{m}^{-2} \mathrm{~d}^{-1}$ at 150 and $300 \mathrm{~m}$ depth, respectively (Table 2). The DIC flux also decreased with water depth from $\sim 13 \mathrm{mmol} \mathrm{m} \mathrm{m}^{-2} \mathrm{~d}^{-1}$ at $4 \mathrm{~m}$ to $\sim 7 \mathrm{mmol} \mathrm{m} \mathrm{m}^{-2} \mathrm{~d}^{-1}$ at $300 \mathrm{~m}$ depth (Table 2). The ratio of $\mathrm{O}_{2}$ :DIC flux was $\sim 1.1$ at the 3 investigated stations. In general, little nitrogen left the sediment as $\mathrm{NO}_{3}{ }^{-}$and $\mathrm{NH}_{4}{ }^{+}$at all stations, and the nitrogen efflux decreased with water column depth (Table 2)

\section{Sediment denitrification}

In contrast to the sediment-water fluxes, denitrification increased with water column depth (Table 2). A 

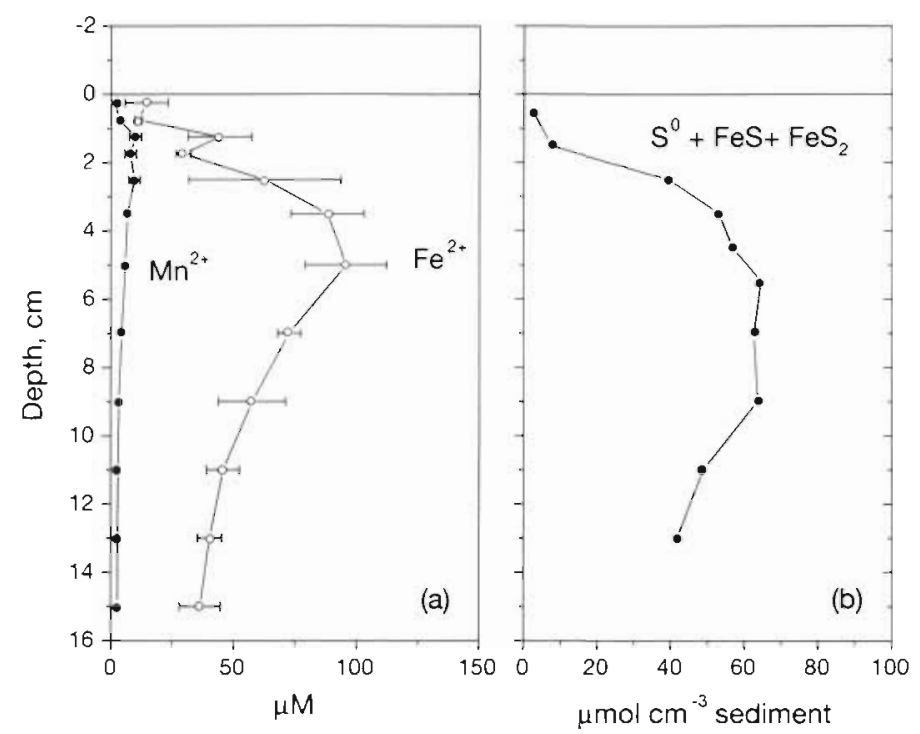

Fig. 6. (a) Porewater concentration profiles of reduced iron $\left(\mathrm{Fe}^{2+}\right)$ and manganese $\left(\mathrm{Mn}^{2+}\right)$, and (b) depth distribution of total sulfur solid species in the sediment of the $300 \mathrm{~m}$ locality in

Disko Bay. Error bars represent standard error, $n=3$

relatively higher bottom-water concentration of $\mathrm{NO}_{3}{ }^{-}$ was observed at the deep-water stations compared to the shallow-water station (Table 1). Separating the rates of denitrification into denitrification depending on water column $\mathrm{NO}_{3}{ }^{-}\left(D_{w}\right)$ and denitrification depending on $\mathrm{NO}_{3}{ }^{-}$from nitrification $\left(D_{n}\right)$, according to the scheme of Nielsen (1992), showed that denitrification was mainly based on $\mathrm{NO}_{3}{ }^{-}$being produced by nitrification within the sediment 79 to $85 \%$ of total denitrification) in all investigated sediments.

\section{Sulfate reduction}

The highest sulfate reduction activities were found between 2 and $5 \mathrm{~cm}$ depth within the sediment of both Stn 1 and Stn 3, although sulfate reduction was low at the deep-water station (Fig. 7). The depth-integrated (0 to $14 \mathrm{~cm}$ ) sulfate reduction rates were 6.4 and $0.4 \mathrm{mmol} \mathrm{m}^{-2} \mathrm{~d}^{-1}$ at the $4 \mathrm{~m}$ and the $300 \mathrm{~m}$ stations, respectively (Table 2 ).

\section{Meiofauna}

No macrofauna was observed in our sediment samples. However, meiofauna was present in the sediment of both shallow and deep waters of Disko Bay. At both stations, the highest number of individuals was found in the upper $2 \mathrm{~cm}$ (Fig. 8). The highest number of individuals per $\mathrm{cm}^{3}$ was found in the
Table 2. Fluxes, denitrification and sulfate reduction in Disko Bay $\left(\mathrm{mmol} \mathrm{m} \mathrm{m}^{-2} \mathrm{~d}^{-1}\right)$. All numbers are from dark incubated cores. Standard errors are shown, $n=6$. nd: not determined

\begin{tabular}{|lccc|}
\hline & $\begin{array}{c}\text { Stn 1, } \\
\text { Itarlaa, } 4 \mathrm{~m}\end{array}$ & $\begin{array}{c}\text { Stn 2, } \\
\text { Kuannit, } 150 \mathrm{~m}\end{array}$ & $\begin{array}{c}\mathrm{Stn} 3, \\
\text { Kuannit, } 300 \mathrm{~m}\end{array}$ \\
\hline $\mathrm{O}_{2}$ consumption & $14.4 \pm 1.7$ & $9.8 \pm 0.7$ & $8.0 \pm 1.0$ \\
$\mathrm{DIC}$ flux & $13.5 \pm 1.2$ & $8.5 \pm 1.8$ & $6.8 \pm 1.2$ \\
$\mathrm{NH}_{4}^{+}$flux & $0.118 \pm 0.090$ & $0.071 \pm 0.027$ & $0.047 \pm 0.006$ \\
$\mathrm{NO}_{3}{ }^{-}$flux & $0.051 \pm 0.031$ & $-0.070 \pm 0.039$ & $0.02 \pm 0.010$ \\
Denitrification & $0.2 \pm 0.1$ & $1.5 \pm 0.6$ & $1.8 \pm 0.4$ \\
Sulfate reduction & 6.4 & nd & 0.4 \\
\hline
\end{tabular}

upper $3 \mathrm{~mm}$ of $\mathrm{Stn} 1$ (203 ind. $\mathrm{cm}^{-3}$ ). In the top $9 \mathrm{~mm}$ of the sediment, the population was dominated by nauplia, while Nematoda was the dominating taxon below this depth. Together, nematodes and nauplia constituted $87 \%$ of the total number of individuals in the core, and in each investigated section they always constituted between 78 and $92 \%$ of the total number of individuals (Table 3 ). The third most wellrepresented phylum was Gastrotricha. The counted specimens could be divided into the 2 orders, Macrodasyida and Chaetonotida, with the macrodasyids generally being the dominant one. Macrodasyids live exclusively in the interstices of marine, sandy sediments (Swedmark 1964). Both orders appeared in the largest numbers between 3 and $12 \mathrm{~mm}$ in the sediment. Meiofauna was still present at a depth of 9 to $10 \mathrm{~cm}$, and it is likely that meiofauna existed even deeper in the sediment but it was not included in this study.
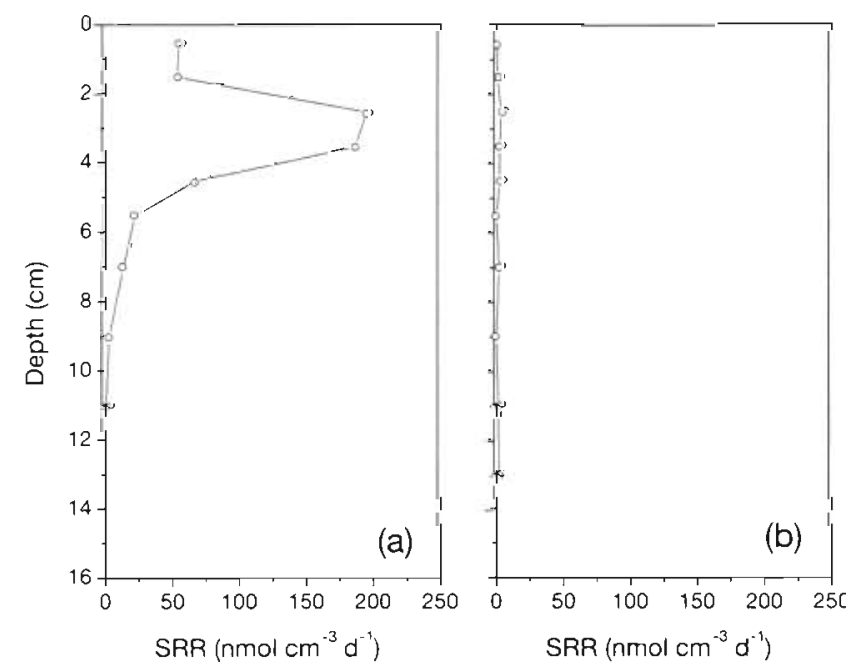

Fig. 7. Vertical distribution of sulfate reduction rates (SRR) in the sediment of (a) the shallow-water, sandy locality and (b) the muddy, $300 \mathrm{~m}$ locality in Disko Bay 

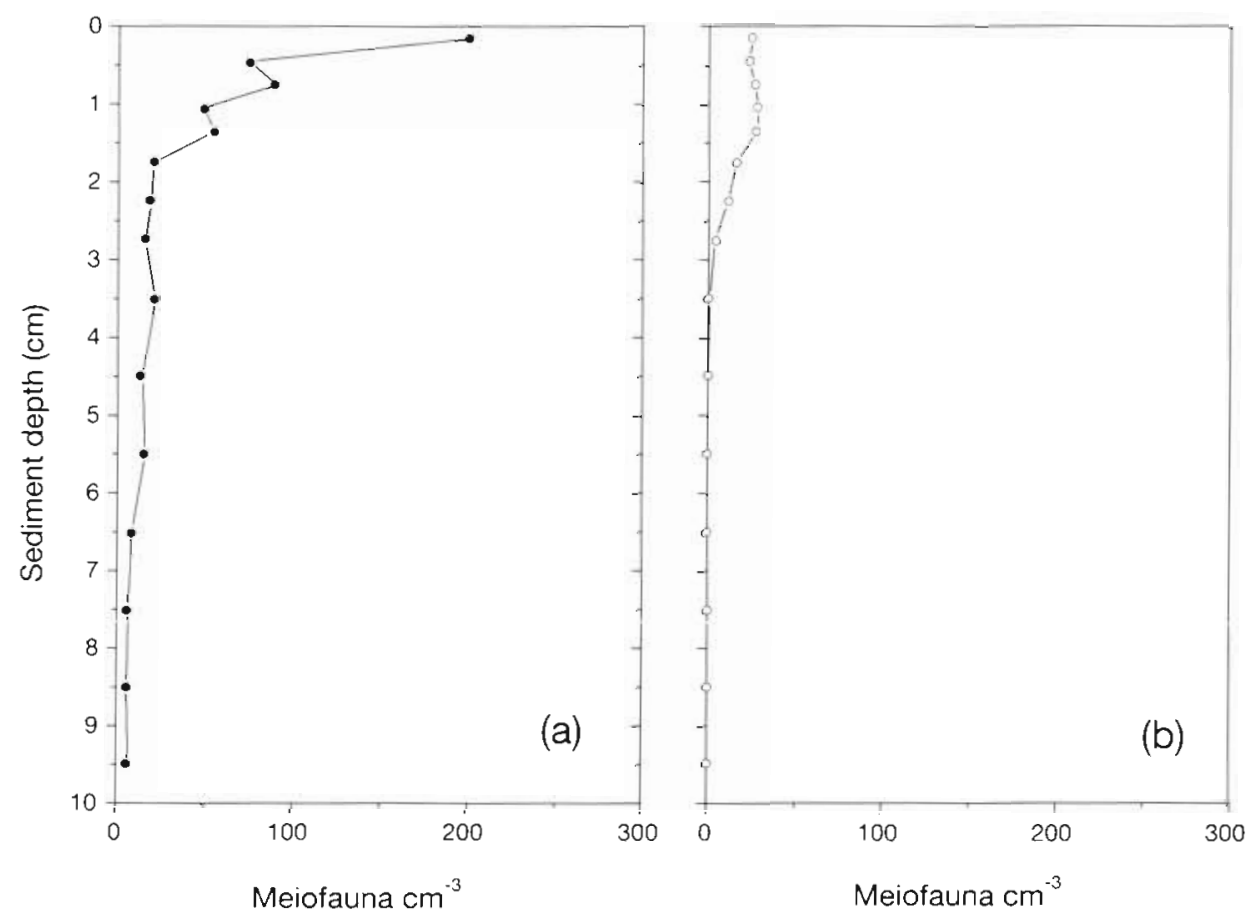

Fig. 8. Vertical distribution of meiofauna at (a) the $4 \mathrm{~m}$, shallow-water locality and (b) the muddy, $300 \mathrm{~m}$ locality in Disko Bay

At Stn 3 nematodes constituted the most well-represented taxon. The nematodes were totally dominant in all layers, except for the depth interval of 0 to $3 \mathrm{~mm}$, where foraminifers were found in higher numbers. In the upper layers the nematodes were found in relatively low numbers, but the number of individuals per $\mathrm{cm}^{3}$ increased and peaked at a depth of 12 to $15 \mathrm{~mm}$. The other taxa showed almost similar distribution patterns and were all represented in highest numbers in the upper sediment layer, after which they gradually decreased with sediment depth. Below $25 \mathrm{~mm}$ depth only nematodes were recorded, and below $4 \mathrm{~cm}$ no animals were recorded at all.

Stns 1 and 3 differ from one another with respect to number of individuals as well as to the composition of taxa and their vertical distribution. First of all, considerably higher numbers of individuals were found in the sand at Stn 1 (5475 ind.) compared to the mud at Stn 3 (1217 ind.). Secondly, taxa such as Platyhelminthes, Rotifera, Gastrotricha and Protodriloidae (Polychaeta) were only found at Stn 1, while KinoIhyncha, Foraminifera and Cumacea (Crustacea) were only present at Stn 3 (Table 3). Finally, the distribution patterns of the nematodes differed between the 2 stations. At Stn 1 they were found in high numbers at 3 to $12 \mathrm{~mm}$ depth, while the number of nematodes at Str 3 was almost constant in the depth interval of 0 to $12 \mathrm{~mm}$, after which the number decreased to zero at 40 mm depth (Fig. 8).

\section{DISCUSSION}

\section{Sediment-water fluxes}

The sediment $\mathrm{O}_{2}$ consumption and DIC flux (Table 2) are comparable with rates found in other arctic areas (Pfannkuche \& Thiel 1987, Grebmeier \& McRoy 1989. Henriksen et al. 1993, Glud et al. 1998, Rysgaard et al. 1998). Furthermore, our rates are as high as those observed in several temperate regions with much higher temperatures (Rasmussen \& Jørgensen 1992, Canfield et al. 1993, Devol \& Christensen 1993, Thamdrup et al. 1996), indicating that benthic mineralization in arctic sediments is controlled by carbon availability rather than by temperature (Grebmeier \& McRoy 1989. Glud et al. 1998, Rysgaard et al. 1998).

The relatively low fluxes of $\mathrm{NH}_{4}{ }^{+}$and $\mathrm{NO}_{3}{ }^{-}$at the shallow-water station (Table 2) are most likely the result of nutrient uptake by the benthic microalgae inhabiting the upper few mm of the sediment. Microalgae are known to be highly efficient in taking up nutrients (Henriksen et al. 1980, Sundbäck \& Granéli 1988, Risgaard-Petersen et al. 1994), even during night (Cochlan et al. 1991, Rysgaard et al. 1993), and thereby reducing the flux of nutrients from the sediment to the overlying water. As benthic microalgae were absent at the deep-water stations, high nitrification and denitrification rates at these stations seemed to explain the very low $\mathrm{NH}_{4}{ }^{+}$and $\mathrm{NO}_{3}{ }^{-}$fluxes there. 
Table 3. Vertical distribution of meiofauna. Numbers are observations of individuals in a sediment core $\left(22 \mathrm{~cm}^{2}\right)$

\begin{tabular}{|c|c|c|c|c|c|c|c|c|c|c|}
\hline $\begin{array}{l}\text { Stn 1, Itarlaa } \\
\text { Sampling } \\
\text { depth (mm) }\end{array}$ & $e^{a x+4}$ & $6 e^{5}$ & $3^{e^{50}}$ & $N^{2}$ & $a^{2 a^{3 y^{2}}} c^{2}$ & $4 x^{25}$ & $4_{a v 0}$ & $p^{000}$ & $5 i^{\circ}$ & $\left\langle o^{+a t}\right.$ \\
\hline $0-3$ & 24 & 10 & 110 & 26 & 3 & 74 & 1090 & 0 & 0 & 1337 \\
\hline $3-6$ & 16 & 0 & 163 & 42 & 7 & 27 & 241 & 0 & 0 & 496 \\
\hline $6-9$ & 21 & 0 & 227 & 38 & 8 & 11 & 296 & 0 & 0 & 601 \\
\hline $9-12$ & 19 & 0 & 178 & 40 & 11 & 0 & 72 & 0 & 0 & 320 \\
\hline $12-15$ & 9 & 0 & 222 & 27 & 2 & 0 & 103 & 0 & 0 & 363 \\
\hline $15-20$ & 10 & 0 & 187 & 11 & 5 & 1 & 9 & 0 & 0 & 223 \\
\hline $20-25$ & 1 & 0 & 199 & 2 & 7 & 0 & 3 & 0 & 0 & 212 \\
\hline $25-30$ & 7 & 0 & 160 & 4 & 3 & 0 & 0 & 0 & 0 & 174 \\
\hline $30-40$ & 15 & 0 & 426 & 24 & 10 & 1 & 0 & 4 & 0 & 480 \\
\hline $40-50$ & 6 & 0 & 284 & 14 & 6 & 1 & 1 & 2 & 0 & 314 \\
\hline $50-60$ & 17 & 0 & 280 & 36 & 15 & 0 & 0 & 1 & 0 & 349 \\
\hline $60-70$ & 7 & 0 & 174 & 8 & 0 & 0 & 0 & 0 & 0 & 189 \\
\hline $70-80$ & 7 & 0 & 124 & 11 & 0 & 0 & 0 & 1 & 0 & 143 \\
\hline $80-90$ & 10 & 0 & 113 & 5 & 0 & 0 & 0 & 0 & 0 & 128 \\
\hline $90-100$ & 11 & 0 & 122 & 7 & 0 & 1 & 0 & 4 & 1 & 146 \\
\hline Total & 180 & 10 & 2969 & 295 & 77 & 116 & 1815 & 12 & 1 & 5475 \\
\hline \multicolumn{11}{|c|}{ Stn 3, Kuannit, $300 \mathrm{~m}$} \\
\hline $\begin{array}{l}\text { Sampling } \\
\text { depth (mm) }\end{array}$ & $x^{00 x^{2}}$ & $\beta^{5} 5^{\circ 0^{\circ}}$ & se & & $\mathrm{cos}^{\mathrm{m}^{\mathrm{a}^{\mathrm{c}^{2}}}}$ & $+2 a^{2} 9^{2 c}$ & $\rho^{2} v \rho^{i \gamma^{2}}$ & polych & $g^{d x}$ & $\left\langle\theta^{(a)}\right.$ \\
\hline $0-3$ & 66 & 2 & 54 & & 1 & 29 & 11 & 2 & 2 & 163 \\
\hline $3-6$ & 26 & 16 & 66 & & 1 & 21 & 22 & 0 & 0 & 152 \\
\hline $6-9$ & 19 & 15 & 108 & & 1 & 20 & 10 & 0 & 1 & 173 \\
\hline $9-12$ & 12 & 17 & 139 & & 0 & 12 & 8 & 2 & 0 & 188 \\
\hline $12-15$ & 7 & 8 & 155 & & 0 & 12 & 0 & 0 & 0 & 182 \\
\hline $15-20$ & 1 & 2 & 168 & & 0 & 3 & 0 & 0 & 0 & 174 \\
\hline $20-25$ & 3 & 0 & 118 & & 0 & 2 & 0 & 1 & 0 & 123 \\
\hline $25-30$ & 0 & 0 & 41 & & 0 & 0 & 0 & 0 & 0 & 41 \\
\hline $30-40$ & 0 & 0 & 21 & & 0 & 0 & 0 & 0 & 0 & 21 \\
\hline $40-50$ & 0 & 0 & 0 & & 0 & 0 & 0 & 0 & 0 & 0 \\
\hline $50-100$ & 0 & 0 & 0 & & 0 & 0 & 0 & 0 & 0 & 0 \\
\hline Total & 134 & 60 & 870 & & 3 & 99 & 51 & 5 & 3 & 1217 \\
\hline
\end{tabular}

\section{Sediment denitrification rates and concentration profiles of $\mathrm{NH}_{4}{ }^{+}$and $\mathrm{NO}_{3}{ }^{-}$}

Denitrification rates were 6 to 9 times higher at the deep-water stations in Disko Bay compared to the $4 \mathrm{~m}$ deep station (Table 2). The lower denitrification rates at the shallow-water station were caused by competition between benthic microalgae and bacterial nitrification and denitrification for $\mathrm{NH}_{4}{ }^{+}$and $\mathrm{NO}_{3}{ }^{-}$, as previously reported in detail by Rysgaard et al. (1995).

The denitrification rates at the deep-water stations are comparable to rates reported from the Bering, Chukchi and Beaufort Seas (Henriksen et al. 1993, Devol et al. 1997) but higher than rates reported from the east coast of Greenland (Rysgaard et al. 1998) and Svalbard (Glud et al. 1998). Furthermore, the rates are of the same magnitude as those in temperate sediments (Jenkins \& Kemp 1984, Seitzinger 1990, Nielsen 1992, Rysgaard et al. 1995, Lohse et al. 1996). Denitri- fication at the deep-water stations was stimulated by a high bottom-water $\mathrm{NO}_{3}{ }^{-}$concentration and an efficient coupling between nitrification and denitrification as demonstrated by both the isotope-pairing measurements and the $\mathrm{NH}_{4}{ }^{+}$and $\mathrm{NO}_{3}{ }^{-}$concentration profiles within the sediment (Fig. 5). Thus, a net $\mathrm{NH}_{4}{ }^{+}$consumption zone was found within the oxic surface layers of the sediment due to high nitrification activity (Fig. 5a). Furthermore, immediately below the oxic zone a distinct zone of $\mathrm{NH}_{4}{ }^{+}$production $\left(\sim 0.17 \mathrm{mmol} \mathrm{N} \mathrm{m}{ }^{-2} \mathrm{~d}^{-1}\right)$ was evident. Assuming that this $\mathrm{NH}_{4}{ }^{+}$production was due only to bacterial denitrification according to the reaction:

$$
\begin{gathered}
\left(\mathrm{CH}_{2} \mathrm{O}\right)\left(\mathrm{NH}_{3}\right)_{1 /(\mathrm{C} / \mathrm{N})}+0.8 \mathrm{NO}_{3}{ }^{-}+0.8 \mathrm{H}^{+} \rightarrow \\
\mathrm{CO}_{2}+\frac{1}{(\mathrm{C} / \mathrm{N})} \mathrm{NH}_{3}+0.4 \mathrm{~N}_{2}+1.4 \mathrm{H}_{2} \mathrm{O}
\end{gathered}
$$

where $\left(\mathrm{CH}_{2} \mathrm{O}\right)\left(\mathrm{NH}_{3}\right)_{1 /(\mathrm{C} / \mathrm{N})}$ represents organic matter with a $\mathrm{C} / \mathrm{N}$ ratio of 12 (Fig. 2), denitrification would 
amount to $\sim 1.6 \mathrm{mmol} \mathrm{N} \mathrm{m}^{-2} \mathrm{~d}^{-1}$, which is very close to the direct measured rate of $1.8 \pm 0.4 \mathrm{mmol} \mathrm{N} \mathrm{m}^{-2} \mathrm{~d}^{-1}$ (Table 2). This interpretation of the $\mathrm{NH}_{4}{ }^{+}$concentration profiles demonstrates that denitrification accounts for a significant fraction of total organic degradation, and that the anaerobic processes going on deeper in the sediment, such as iron and sulfate reduction, may be less important processes in the mineralization of organic matter at this $300 \mathrm{~m}$ station in Disko Bay.

The measured porewater concentration profile of $\mathrm{NO}_{3}{ }^{-}$exhibited dubiously high $\mathrm{NO}_{3}{ }^{-}$concentrations deep in the sediment (Fig. 5b), which are not in agreement with data obtained by $\mathrm{NO}_{3}{ }^{-}$microsensor measurements (Rysgaard unpubl.). In addition, we have observed on several occasions subsequent to this study that porewater squeezing may significantly alter the true in situ $\mathrm{NO}_{3}{ }^{-}$concentration profile, since increasing pressure on sediments increases the amount of $\mathrm{NO}_{3}^{-}$that can be extracted from the sediment. However, using the isotope-pairing measurements of denitrification (Table 2) and fits of the $\mathrm{O}_{2}$ (Fig. 9a) and $\mathrm{NH}_{4}{ }^{+}$(Fig. 9b) concentration profiles as input to the model of Rysgaard \& Berg (1996), the expected steady-state $\mathrm{NO}_{3}{ }^{-}$concentration profile can be simulated (Fig. 9c). The depth-dependent nitrification activity was calculated as $\mathrm{K}_{\text {nit }}\left[\mathrm{O}_{2}\right]\left[\mathrm{NH}_{4}{ }^{+}\right]$, where $K_{\text {nit }}$ is a constant and $\left[\mathrm{O}_{2}\right]$ and $\left[\mathrm{NH}_{4}{ }^{+}\right]$are the fitted concentration profiles. Likewise, the denitrification rate was expressed as $K_{\text {denit }}\left[\mathrm{NO}_{3}{ }^{-}\right]$, with the addition that this process was inhibited $100 \%$ when the $\mathrm{O}_{2}$ concentrations exceeded $5 \mu \mathrm{M}$. The simulation predicts that the nitrification activity has to be located spatially close to the denitrification zone in order to be consistent with the measured low efflux of $\mathrm{NO}_{3}{ }^{-}$from the sediment. From the relatively few studies of $\mathrm{NO}_{3}{ }^{-}$ microsensor measurements, $\mathrm{NO}_{3}^{-}$does indeed seem to be consumed by denitrification immediately below the oxic zone (Sweerts \& De Beer 1989, Jensen et al. 1994, Berg et al. 1998, Lorenzen et al. 1998), which is in agreement with our simulated $\mathrm{NO}_{3}{ }^{-}$concentration profile. Finally, the maximum nitrification activity in the referred studies was observed near the oxicanoxic interface as simulated here. Thus, we believe that the simulated $\mathrm{NO}_{3}{ }^{-}$concentration profile is correct, and that the high $\mathrm{NO}_{3}{ }^{-}$concentration measured deeper in the sediment is an artifact presumably caused by internal $\mathrm{NO}_{3}{ }^{-}$pools being liberated during squeezing. Fossing et al. (1995) observed internal nitrate pools of $500 \mathrm{mM}$ in the mat-forming sulphur bacterium Thioploca. In addition, Lomstein et al. (1990) observed high internal pools of $\mathrm{NO}_{3}{ }^{-}$in deposited phytoplankton in a marine sediment. However, further investigations are needed in order to evaluate whether the excess $\mathrm{NO}_{3}{ }^{-}$in our Disko Bay sediment is caused by bacterial or plankton pools.

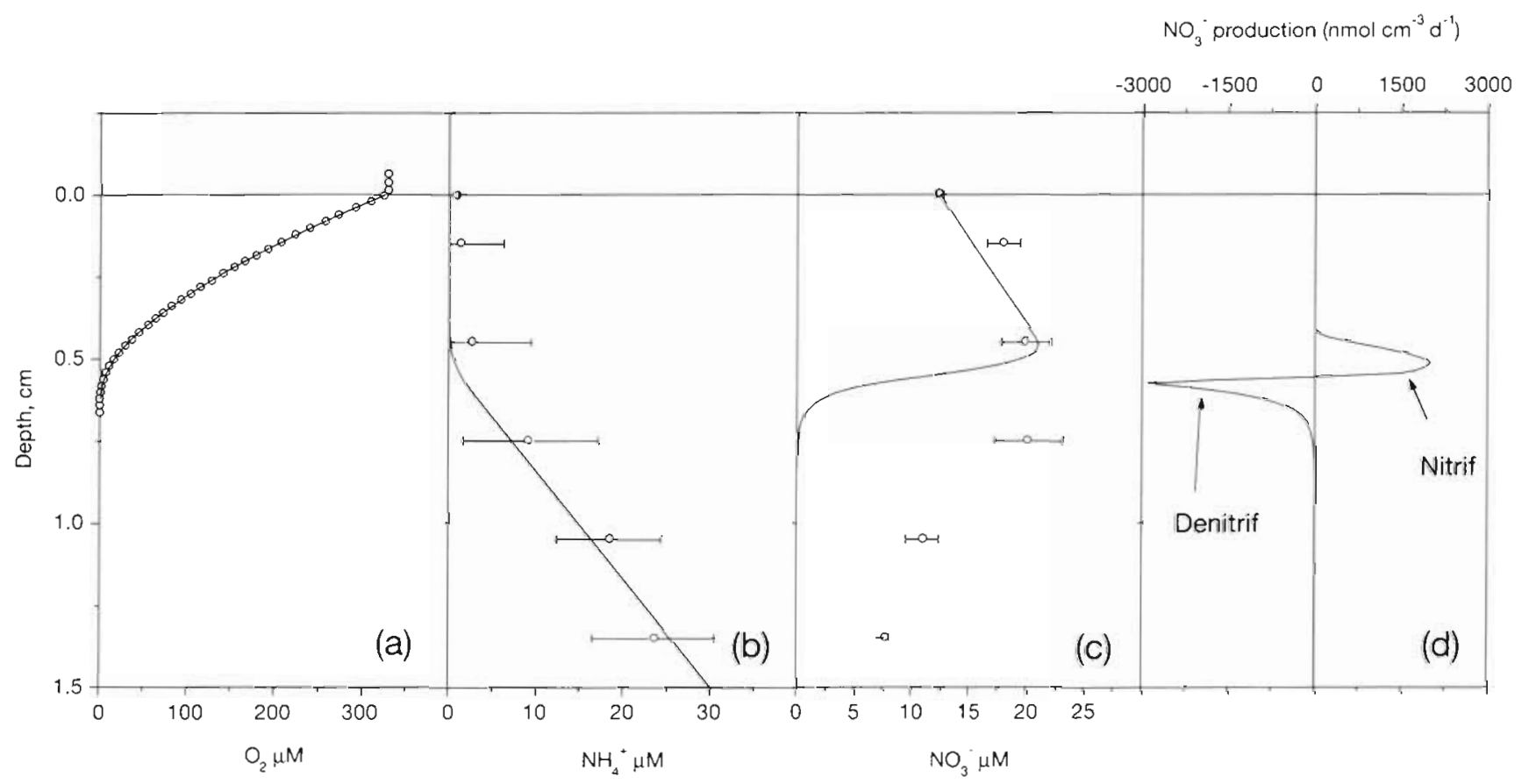

Fig. 9. Model input of vertical concentration profiles of (a) $\mathrm{O}_{2}$ and (b) $\mathrm{NH}_{4}{ }^{+}$, assuming that denitrification is inhibited by $\mathrm{O}_{2}$ concentrations $>5 \mu \mathrm{M}$, and (c) measured (o) and simulated (-) concentrations of $\mathrm{NO}_{3}{ }^{-}$, as well as (d) the predicted vertical distribution and activity of nitrification and denitrification in the $300 \mathrm{~m}$, deep-water sediment of Disko Bay. (See text for further details) 


\section{Sulfate reduction rates}

The sulfate reduction rate measured at the shallowwater station was high and comparable with rates from the Bering, Chukchi and Beaufort Seas (Devol et al. 1997). Sulfate reduction rates were much lower at the $300 \mathrm{~m}$ station in Disko Bay but were comparable at this water depth with the lower values measured in sediments from East Greenland (Rysgaard et al. 1998) and Svalbard (Sagemann et al. 1998). Overall, sulfate reduction rates in these cold polar regions are comparable with rates in sediments with much higher ambient temperatures, which further supports the hypothesis that substrate availability, and not temperature, limits bacterial activity in cold sediments.

\section{Meiofauna distribution and effect on bacterial mineralization}

The abundance of the total interstitial meiofauna of 2489 ind. $10 \mathrm{~cm}^{-2}$ at the shallow-water station is higher than what has been observed in many other subtidal sandy sediments at similar depths in other parts of the world (Coull 1988). However, it is comparable with the data of Coull (1985) from the SE Atlantic. Kristensen \& Norrevang (1982) explained the rich and diversified interstitial fauna in the Bay of Iterlaa, the site of our Stn 1, with the presence of a sediment consisting of well-sorted medium sand protected by an offshore barrier preventing ice rafting, conditions which are rarely seen in the Arctic.

The abundance and composition of meiofauna at the $300 \mathrm{~m}$ station in Disko Bay is comparable with muddy sediments from similar depths worldwide (Coull 1988). The amount of meiofauna decreased with sediment depth at both the shallow- and deep-water stations in Disko Bay, with the highest numbers observed in the upper $2 \mathrm{~cm}$ (61 to $85 \%$ of the total was found here, Fig. 8). It has been suggested that sulfide may have a profound impact on infauna abundance and composition in the sediment (Fenchel \& Riedl 1970). No free sulfide, however, was detected in the sediments of Disko Bay and, given that meiofauna mainly feeds on bacteria and benthic diatoms (Montagna 1984) and that the highest microbial activity was found in the upper sediment layers (Figs. 3 \& 7 ), where the highest concentration of organic carbon was also present (Fig. 2), it seems likely that the vertical distribution of meiofauna in the sediments studied here was primarily regulated by the amount of organic matter.

It has previously been shown that meiofauna can enhance transport of solutes in sediments (Aller \& Aller 1992, Berg et al. 1999, Glud \& Fenchel 1999) and there- by enhance carbon degradation. Berg et al. (unpubl.) suggested an indirect way of evaluating the effect of meiofauna on transport of solutes in the sediments. They calculated values of $D_{\mathrm{B}}$ (bioturbation coefficient) from the difference between the $\mathrm{O}_{2}$ flux obtained by direct flux measurements and the $\mathrm{O}_{2}$ flux found by $\mathrm{O}_{2}$ concentration profile interpretations where only molecular diffusion was included. In the sediment of the $300 \mathrm{~m}$ station, interpretation of the $\mathrm{O}_{2}$ concentration profile gave an $\mathrm{O}_{2}$ flux of $5.3 \mathrm{mmol} \mathrm{m} \mathrm{m}^{-2} \mathrm{~d}^{-1}$ while direct measurements gave a larger flux of $8.0 \mathrm{mmol}$ $\mathrm{m}^{-2} \mathrm{~d}^{-1}$ (Table 2). Assuming that the difference was caused by meiofaunal activity, the bioturbation coefficient can be estimated as $4.0 \times 10^{-6} \mathrm{~cm}^{2} \mathrm{~s}^{-1}$ (for further details see Berg et al. 1999). A similar estimate for the shallow-water, sandy station gave a $D_{B}$ value of $11.9 \times$ $10^{-6} \mathrm{~cm}^{2} \mathrm{~s}^{-1}$. The ratio between these $2 D_{\mathrm{B}}$ values is 3.0 , which is equal to the ratio between the numbers of meiofauna individuals (3340:1032) in the upper $2 \mathrm{~cm}$ of the sediment at the 2 stations. Thus, it seems likely that the difference in number of meiofauna is responsible for the difference in bioturbation in the upper sediment layers between the 2 stations, and that meiofauna therefore increased the transport of solutes in the Disko Bay sediment by a factor of 1.5 to 3.1 in accordance with observations made by Aller \& Aller (1992).

\section{Carbon mineralization}

To estimate the relative contribution of anaerobic and aerobic processes to total carbon mineralization, DIC fluxes (Table 2) were used as a measure of total carbon mineralization in the sediment. Rates of sulfate reduction were converted to carbon units using a stoichiometry of $1 \mathrm{~mol}$ of $\mathrm{SO}_{4}{ }^{2-}$ to $2 \mathrm{~mol}$ of organic carbon, and denitrification was converted to carbon units with a reaction stoichiometry of $1 \mathrm{~mol}$ of $\mathrm{NO}_{3}{ }^{-}$to $1.25 \mathrm{~mol}$ of organic carbon. To evaluate the importance of organotrophic $\mathrm{O}_{2}$ respiration, carbon oxidation by denitrification and sulfate reduction were subtracted from the total carbon mineralization (DIC flux). Integrating over the upper $15 \mathrm{~cm}$ of the sediment resulted in the relative contributions of aerobic and anaerobic processes within Disko Bay as shown in Table 4. Sulfate reduction dominated the organic carbon mineralization in the shallow-water sediment, whereas organotrophic $\mathrm{O}_{2}$ respiration and denitrification dominated the deep-water, muddy station. The present study shows that denitrification may be an important contributor to total carbon oxidation in some systems, being responsible for 22 to $33 \%$ of total carbon oxidation at the deep-water stations in Disko Bay. 
Table 4. Rates of sedimentary processes ( $\operatorname{mmol} \mathrm{C} \mathrm{m}^{-2} \mathrm{~d}^{-1}$ ) and importance of the different carbon oxidation pathways in Disko Bay. Numbers in brackets represent \% of total $\mathrm{C}$ oxidation. SRR: sulfate reduction rate

\begin{tabular}{|lccc|}
\hline & $\begin{array}{c}\text { Stn 1, } \\
\text { Itarlaa, 4 m }\end{array}$ & $\begin{array}{c}\text { Stn 2, } \\
\text { Kuannit, 150 m }\end{array}$ & $\begin{array}{c}\text { Stn 3, } \\
\text { Kuannit, 300 m }\end{array}$ \\
\cline { 1 - 2 } O $_{2}$ respiration & $0.4(3)$ & & $3.7(55)$ \\
Denitrification & $0.3(2)$ & $1.9(22)$ & $2.3(33)$ \\
SRR & $12.8(95)$ & & $0.8(12)$ \\
Total & $13.5(100)$ & $8.5(100)$ & $6.8(100)$ \\
\hline
\end{tabular}

Acknowledgements. This study was financially supported by the Danish Research Councils (contract no. 9501025 and 9700224). We thank the crew of RV 'Porsild' for help in the field. Anna Haxen is thanked for technical assistance in the field and laboratory and for linguistic corrections. Henrik Fossing and Kitte Gerlich are thanked for the measurements of sulfur components and Bo Thamdrup for measurements of iron and manganese components.

\section{LITERATURE CITED}

Aller RC, Aller JY (1992) Meiofauna and solute transport in marine muds. Limnol Oceanogr 37:1018-1033

Andersen OGN (1981) The annual cycle of phytoplankton primary production and hydrography in the Disko Bugt area, West Greenland. Medd Grønl Biosci 6:3-65

Berg P, Risgaard-Petersen N, Rysgaard S (1998) Interpretation of measured concentration profiles in sediment pore water. Limnol Oceanogr 6:1500-1510

Bower C, Holm-Hansen T (1980) A salicylate-hypochlorite method for determining ammonia in seawater. Can J Fish Aquat Sci 37:794-798

Braman RS, Hendrix SA (1989) Nanogram nitrite and nitrate determination in environmental and biological meterials by vanadium (III) reduction with chemiluminescence detection. Anal Chem 61:2715-2718

Broecker WS, Peng TH (1974) Gas exchange rates between air and sea. Tellus 26:21-35

Canfield DE, Jørgensen BB, Fossing $H$, Glud R, Gundersen $J$, Ramsing NB, Thamdrup B, Hansen JW, Nielsen LP, Hall POJ (1993) Pathways of organic carbon oxidation in three continental margin sediments. Mar Geol 113:27-40

Cline JD (1969) Spectrophotometric determination of hydrogen sulfide in natural waters. Limmol Oceanogr 14:454-458

Cochlan WP, Harrison PJ, Denman KL (1991) Diel periodicity of nitrogen uptake by marine phytoplankton in nitraterich environments. Limnol Oceanogr 36:1689-1700

Coull BC (1985) Long-term variability of estuarine meiobenthos. Mar Ecol Prog Ser 24:205-218

Coull BC (1988) Ecology of the marine meiofauna. In: Higgins $\mathrm{RB}$, Thiel $\mathrm{H}$ (eds) Introduction to the study of meiofauna. Smithsonian Institution Press, Washington, p 18-38

Devol AH, Christensen JP (1993) Benthic fluxes and nitrogen cycling in sediments of the continental margin of the eastern North Pacific. J Mar Res 51:345-372

Devol AH, Codispoti LA, Christensen JP (1997) Summer and winter denitrification rates in western arctic shelf sediments. Cont Shelf Res 17:1029-1050
Fenchel T, Riedl RJ (1970) The sulfide system: a new biotic community underneath the oxidized layer of marine sand bottoms. Mar Biol 7:255-268

Fossing H, Jørgensen BB (1989) Measurement of bacterial sulfate reduction in sediments: evaluation of a single-step chromium reduction method. Biogeochemistry 8:205-222

Fossing $H$, Gallardo VA, Jørgenen BB, Hüttel M, Nielsen LP, Schulz H, Canfield DE, Foster S, Glud RN, Gundersen JK, Küver J, Ramsing NB, Teske A, Thamdrup B, Ulloa O (1995) Concentration and transport of nitrate by the mat-forming sulphur bacterium Thioploca. Nature 374:713-715

Glud RN, Fenchel T (1999) The importance of ciliates for interstitial transport in marine sediments. Mar Ecol Prog Ser $186: 87-93$

Glud RN, Holby O, Hoffmann F, Canfield DE (1998) Benthic mineralization and exchange in arctic sediments (Svalbard, Norway). Mar Ecol Prog Ser 173:237-251

Grasshoff K, Erhardt M, Kremling K (1983) Methods of seawater anaiysis. 2 nd revised and extended version. Verlag Chemie, Weinheim

Grebmeier JM, McRoy CP (1989) Pelagic-benthic coupling on the shelf of the northern Bering and Chukchi Seas. III. Benthic food supply and carbon cycling. Mar Ecol Prog Ser 53:79-91

Hall POJ, Aller RC (1992) Rapid, small-volume, flow injection for analysis for total $\mathrm{CO}_{2}$ and $\mathrm{NH}_{4}{ }^{+}$in marine and freshwaters. Limnol Oceanogr 37:1113-1119

Hansen BW, Nielsen TG, Levinsen H (1999) Plankton community structure and carbon cycling on the western coast of Greenland during the stratified summer situation. III. Mesozooplankton. Aquat Microb Ecol 16:233-249

Henriksen K, Hansen J, Blackburn TH (1980) The influence of benthic infauna on exchange rates of inorganic nitrogen between sediment and water. Ophelia 1:249-256

Henriksen K, Blackburn TH, Lomstein B, McRoy CP (1993) Rates of nitrification, distribution of nitrifying bacteria and inorganic $N$ fluxes in northern Bering-Chuckchi shelf sediments. Cont Shelf Res 13:629-651

Higgins RP, Kristensen RM (1988) Kinorhyncha from Disko Island, West Greenland. Smithson Contrib Zool 458:1-56

Iversen N, Jørgensen BB (1993) Diffusion coefficients of sulfate and methane in marine sediments: influence of porosity. Geochim Cosmochim Acta 57:571-578

Jenkins MC, Kemp WM (1984) The coupling of nitrification and denitrification in two estuarine sediments. Limnol Oceanogr 29:609-619

Jensen K, Sloth NP, Risgaard-Petersen N, Rysgaard S, Revsbech NP (1994) Estimation of nitrification and denitrification from microprofiles of oxygen and nitrate in a model sediment system. Appl Environ Microbiol 60:2094-2100

Jørgensen BB (1978) A comparison of methods for the quantification of bacterial sulfate reduction in coastal marine sediments. I. Measurement with radiotracer techniques. Geomicrobiol J 1:11-27

Jørgensen BB (1996) Case study - Aarhus Bay. In: Jørgensen $\mathrm{BB}$, Richardson K (eds) Eutrophication in coastal and marine ecosystems. American Geophysical Union IV Series, Washington, DC

Kanneworff E, Nicolaisen W (1973) The 'Haps'. A frame-supported bottom corer. Ophelia 10:119-129

Kristensen RM, Niilonen T (1982) Structural studies on Diurodrilus Remane (Diurodrilidae fam.n.) with description of Diurodrilus westheidei sp.n. from the Arctic interstitial meiobenthos, W. Greenland. Zool Scr 11(1):1-12

Kristensen RM, Norrevang A (1982) Description of Psammodrilus aedificator sp.n. (Polychaeta), with notes on the Arctic interstitial fauna of Disko Island, W. Greenland. Zool 
Scr 11(4):265-279

Levinsen H, Nielsen TG, Hansen BW (1999) Plankton community structure and carbon cycling on the western coast of Greenland during a stratified summer situation. II. Ciliates and heterotrophic dinoflagellates. Aquat Microb Ecol $16: 217-232$

Li YH, Gregory S (1974) Diffusion of ions in sea water and in deep-sea sediments. Geochim Cosmochim Acta 38:703-714

Lohse L, Kloosterhuis R, van Raaphorst W. Helder W (1996) Denitrification rates in continental shelf sediments of the North Sea: acetylene block technique versus isotope pairing. Mar Ecol Prog Ser 132:169-179

Lomstein $E_{\text {, Jensen }} \mathrm{MH}$, Sørensen J (1990) Intracellular $\mathrm{NH}_{4}{ }^{*}$ and $\mathrm{NO}_{3}{ }^{-}$pools associated with deposited phytoplankton in a marine sediment (Aarhus Bight, Denmark). Mar Ecol Prog Ser 61:97-105

Lorenzen J, Larsen LH, Kjær T, Revsbech NP (1998) Biosensor determination of the microscale distribution of nitrate, nitrate assimilation, nitrification, and denitrification in a diatom-inhabited freshwater sediment. Appl Environ Microbiol 64:3264-3269

Montagna PA (1984) In situ measurements of meiobenthic grazing rates on sediment bacteria and edaphic diatoms. Mar Ecol Prog Ser 18:119-130

Nielsen LP (1992) Denitrification in sediment determined from nitrogen isotope pairing. FEMS Microbiol Ecol 86: $357-362$

Nielsen TG, Hansen BW (1995) Plankton community structure and carbon cycling on the Arctic coast of western Greenland during and after the sedimentation of a diatom bloom. Mar Ecol Prog Ser 125:239-257

Nielsen TG, Hansen BW (1999) Plankton community structure and carbon cycling on the western coast of Greenland during the stratified summer situation. I. Hydrography, phytoplankton and bacterioplankton. Aquat Microb Ecol 16:205-216

Nybakken JW (1997) Marine biology: an ecological approach, 4 th edn. Harper Collins College Publishers, New York

Patmatmat MM (1973) Benthic community metabolism on the continental terrace and in the deep sea in the North Pacific. Int Rev Ges Hydrobiol 58:345-368

Petersen GH (1964) The hydrography, primary production, bathymetry and 'Tagsâq' of Disko Bay, West Greenland. Medd Gronl 159:1-45

Pfannkuche O, Thiel H (1987) Meiobenthic stocks and benthic activity on the NE-Svalbard Shelf and in the Nansen Basin. Polar Biol 7:253-266

Pfannkuche O, Thiel H (1988) Sample processing. In: Higgins $\mathrm{RB}$, Thiel $\mathrm{H}$ (eds) Introduction to the study of meiofauna. Smithsonian Institution Press, Washington, p 134-145

Rasmussen H, Jørgensen BB (1992) Microelectrode studies of seasonal oxygen uptake in a coastal sediment: role of molecular diffusion. Mar Ecol Prog Ser 81:289-303

Reeburgh WS (1967) An improved interstitial water sampler. Limnol Oceanogr 12:163-165

Revsbech NP (1989) An oxygen microelectrode with a guard cathode. Limnol Oceanogr 34:474-478

Risgaard-Petersen N, Rysgaard S (1995) Nitrate reduction in sediments and waterlogged soil measured by ${ }^{15} \mathrm{~N}$ techniques. In: Alef K, Nannipieri P (eds) Methods in applied

Editorial responsibility: Frede Thingstad,

Bergen, Norway soil and microbiology Academic Press, London, p 287-295

Risgaard-Petersen N, Rysgaard S, Revsbech NP (1993) A sensitive assay for determination of ${ }^{44} \mathrm{~N} /{ }^{15} \mathrm{~N}$ isotope distribution in $\mathrm{NO}_{3}{ }^{-} \mathrm{J}$ Microbiol Methods $17: 155-164$

Risgaard-Petersen N, Rysgaard S, Nielsen LP, Revsbech NP (1994) Diurnal variation of denitrification and nitrification in sediments colonized by benthic microphytes. Limnol Oceanogr 39:573-579

Rysgaard S, Berg P (1996) Mineralization in a northeastern Greenland sediment: mathematical modelling, measured sediment pore water profiles and actual activities. Aquat Microb Ecol 11:297-305

Rysgaard S, Risgaard-Petersen N, Nielsen LP, Revsbech NP (1993) Nitrification and denitrification in lake and estuarine sediments measured by the ${ }^{15} \mathrm{~N}$ dilution technique and isotope pairing. Appl Environ Microbiol 59:2093-2098

Rysgaard S, Christensen PB, Nielsen LP (1995) Seasonal variation in nitrification and denitrification in estuarine sediment colonized by benthic microalgae and bioturbating infauna. Mar Ecol Prog Ser 126:111-121

Rysgaard S, Thamdrup B, Risgaard-Petersen N, Fossing $H$, Berg P, Christensen PB, Dalsgaard T (1998) Seasonal carbon and nutrient mineralization in a high-Arctic coastal marine sediment, Young Sound, Northeast Greenland. Mar Ecol Prog Ser 175:261-276

Sagemann J, Jørgensen BB, Greeff O (1998) Temperature dependence and rates of sulfate reduction in cold sediments of Svalbard, Arctic Ocean. Geomicrobiol J 15:85-100

Seitzinger SP (1990) Denitrification in aquatic sediments. In: Revsbech NP, Sorensen J (eds) Denitrification in soil and sediments. Plenum Press, New York, p 301-322

Smidt ELB (1979) Annual cycles of primary production and of zooplankton at Southwest Greenland. Medd Grønl Biosci $1: 3-53$

Sørensen MV (1998) Marine Rotifera from a sandy beach at Disko lsland, West Greenland, with the description of Encentrum porsildi n. sp. and Notholca angakkoq n. sp. Hydrobiologia 386:153-165

Stookey LL (1970) Ferrozine-a new spectrophotometric reagent for iron. Anal Chem 42:779-781

Sundbäck K, Granéli W (1988) Influence of microphytobenthos on the nutrient flux between sediment and water: a laboratory study. Mar Ecol Prog Ser 43:63-69

Swedmark B (1964) The interstitial fauna of marine sand. Biol Rev 39:1-42

Sweerts JPRA, De Beer D (1989) Microelectrode measurements of nitrate gradients in the littoral and profundal sediment of a meso-eutrophic lake (Lake Vechten. The Netherlands). Appl Environ Microbiol 55:754-757

Tahey TM, Duinveld GCA, Berghuis EM, Helder W (1994) Relation between sediment-water fluxes of oxygen and silicate and faunal abundance at continental shelf, slope and deep-water stations in the northwest Mediterranean. Mar Ecol Prog Ser 104:119-130

Thamdrup B, Canfield DE (1996) Pathways of carbon oxidation in continental margin sediments off central Chile. Limnol Oceanogr 41:1629-1650

Thamdrup B, Canfield DE, Ferdelman G, Glud RN, Gundersen JK (1996) A biogeochemical survey of the anoxic basin Golfo Dulce, Costa Rico. Rev Biol Trop 44:19-33

Submitted: June 5, 1999; Accepted: November 20, 1999

Proofs received from author(s): February 4, 2000 